\title{
Acclimatation of three co-occurring tree species to water stress and their role as site indicators in mixed pine-oak forests in the Sierra Madre Oriental, Mexico
}

\author{
Wibke Himmelsbach • Eduardo J. Treviño-Garza • Humberto González-Rodríguez • \\ Marco A. González-Tagle • Marco V. Gómez Meza • Oscar A. Aguirre Calderón • \\ A. Eduardo Estrada Castillón · Ralph Mitlöhner
}

Received: 14 September 2010/Revised: 22 January 2011/Accepted: 1 March 2011/Published online: 20 March 2011 (c) Springer-Verlag 2011

\begin{abstract}
Water availability and salt excess are limiting factors in Mexican mixed pine-oak forest. In order to characterise the acclimatation of native species to these stresses, leaf water $\left(\Psi_{\mathrm{w}}\right)$ and osmotic potentials $\left(\Psi_{\mathrm{s}}\right)$ of Juniperus flaccida, Pinus pseudostrobus and Quercus canbyi were measured under natural drought and non-drought conditions under two different aspects in the Sierra Madre Oriental. Factorial ANOVA revealed significant differences in $\Psi_{\mathrm{w}}$ and $\Psi_{\mathrm{s}}$ between two aspects, species and sampling dates. In general, all species showed high predawn and low midday values that declined progressively with increasing drought and soil-water loss. Seasonal and diurnal
\end{abstract}

Communicated by A. Merino.

W. Himmelsbach $(\bowtie) \cdot$ E. J. Treviño-Garza •

M. A. González-Tagle · O. A. Aguirre Calderón

Departamento de Silvicultura, Facultad de Ciencias Forestales,

Universidad Autónoma de Nuevo León (UANL),

Apartado Postal 41, Carretera Nacional No 85,

Km 145, 67700 Linares, NL, Mexico

e-mail: wibke.sierramadre@gmail.com

E. J. Treviño-Garza

e-mail: ejtrevin@fcf.uanl.mx

M. A. González-Tagle

e-mail: marcgonza@fcf.uanl.mx

O. A. Aguirre Calderón

e-mail: oaguirre@fcf.uanl.mx

H. González-Rodríguez · A. Eduardo Estrada Castillón Departamento de Ciencias Básicas, Facultad de Ciencias Forestales, Universidad Autónoma de Nuevo León (UANL), Apartado Postal 41, Carretera Nacional No 85, Km 145, 67700 Linares, NL, Mexico

e-mail: humberto@fcf.uanl.mx; humberto@ccr.dsi.uanl.mx fluctuation of $\Psi_{\mathrm{w}}$ and $\Psi_{\mathrm{s}}$ were higher for $J$. flaccida and Q. canbyi than for P. pseudostrobus. Leaf $\Psi_{\mathrm{w}}$ and $\Psi_{\mathrm{s}}$ were mainly correlated with soil water content, while $\Psi_{\mathrm{s}}$ of $P$. pseudostrobus were hardly correlated with environmental variables. Thus, species have different strategies to withstand drought. P. pseudostrobus was identified as a species with isohydric water status regulation, while $J$. flaccida and $Q$. canbyi presented water potential patterns typical for anisohydric species. The type of water status regulation may be a critical factor for plant survival and mortality in the context of climate change. Nevertheless, for precise conclusions about the advantages and disadvantages of each type, further long-term investigations are required.

Keywords Juniperus flaccida · Pinus pseudostrobus . Quercus canbyi - Restoration · Water potential · Osmotic potential

A. Eduardo Estrada Castillón

e-mail: aeduardoestradac@ prodigy.net.mx

M. V. Gómez Meza

Facultad de Economía, Universidad Autónoma de Nuevo León, Monterrey, NL, Mexico

e-mail: marco.gomezmz@uanl.edu.mx

\section{R. Mitlöhner}

Burckhardt-Institute, Tropical Silviculture and Forest Ecology, Faculty of Forest Sciences and Forest Ecology, Georg-August University Göttingen, Büsgenweg 1, 37077 Göttingen, Germany e-mail: rmitloe@gwdg.de 


\section{Introduction}

Mixed pine-oak forests are widely distributed in the higher altitudes of the Eastern Sierra Madre, including ecologically and economically important tree species such as P. pseudostrobus (Rzedowski 1986). These forests are exposed to extreme climatic conditions of high temperatures and low precipitation distributed irregularly through the year. Under field conditions, water stress or rather soil water availability is in general one of the major limiting factors in plant growth and affects most physiological processes in these ecosystems (Kozlowski et al. 1991; Kramer 1983; Kramer and Boyer 1995; Mitlöhner 1998; González et al. 2003). Moreover, water scarcity and high potential evaporation lead to salt excess in the vegetation's rhizospheres, another serious and significant environmental problem that plants have to face in arid and semi-arid environments (Szabolcs 1994; Mitloehner and Koepp 2007). So far, water scarcity, soil salinity as well as climate induced salinity can be considered natural processes, and the native vegetation is adapted to these environmental conditions (Mitloehner and Koepp 2007).

Even so, climatic change makes conditions for plant growth even more acute. The response of forests to these changes is uncertain and has the potential to greatly alter the distribution and productivity of tree species (Pastor and Post 1988; Kramer 1983; Tschaplinski et al. 1998; Rötzer et al. 2005; Ricker et al. 2007). Inappropriate land-use contributes further to the acceleration of forest degradation and deforestation in great parts of the mountain chain Sierra Madre Oriental due to anthropogenic pressures (Domínguez and Návar 2000; Cantú and González 2002; González Tagle et al. 2005). Especially inadequate irrigation and the clearing of deep-rooted native vegetation cause secondary salinisation in dryland areas worsening and/or impeding natural regeneration and reforestation (Szabolcs 1994; Munns 2002; Mitloehner and Koepp 2007). In Chiapas, southern Mexico, the thinning of the canopy in tropical highland forests by human activities increased solar radiation and exposed seedlings and juveniles to more extreme temperatures at the forest floor level, thus decreasing soil moisture availability (Ramírez-Marcial et al. 1996, 2001). The response of forest ecosystems to such climatic and anthropogenic stresses will depend in great part on the drought (Tschaplinski et al. 1998) and salt tolerance of the individual species (Mitloehner and Koepp 2007).

Hence, understanding water uptake patterns, the physiological response of species to water stress, salt excess and their tolerance scope under severe environmental stress is required to explain differences among species in survival and distribution. It also allows determining the relative suitability of species for ecological restoration of degraded lands (Jurado et al. 1998; Ramírez-Marcial et al. 2001; González et al. 2003; Gebrekirstos et al. 2006). Elsewhere, previous works on plant water relations and forest restoration (Gebre et al. 1998; Jurado et al. 1998; Vertovec et al. 2001; González et al. 2003; Gebrekirstos et al. 2006, Mitloehner and Koepp 2007) emphasised the need to investigate water relations of native species and their physiological responses to changes in resource availability. There are few studies in the field of forest ecology and tree ecophysiology from the Sierra Madre Oriental including leaf water and leaf osmotic potential measurement on native tree species.

Plant internal water potential is a consequence of the soil-plant atmospheric continuum and consists of the tension caused by the water pressure deficit of the atmosphere, regulative processes of leaves, general flow regulation resistances and the soil water potential (Philip 1966; Duhme and Richter 1977; Kozlowski et al. 1991; Kramer and Boyer 1995; Donovan et al. 2003). It is a dependable measure of plant and soil water status and quickly measured directly in the field, a great advantage especially for plant comparison (Slatyer 1967; Sala et al. 1981; Pallardy et al. 1991; Kramer and Boyer 1995; Mitlöhner 1998; Vertovec et al. 2001; Donovan et al. 2003). The water balance of a plant becomes negative when the uptake of water is insufficient to meet the requirements of transpiration (Sellin 1998) and plants begin to suffer water stress. Declining water potentials indicate water stress, which can be divided into static stress and dynamic stress. The first one is caused by low water availability in the soil, and the second one results from the resistance of water flow through the plant due to transpirational water loss from foliage, so plant water potentials decline (Tyree and Ewers 1991). The dynamic of leaf water potentials at a certain daytime ( $\Psi_{\text {wmd }}$, in our case at midday) can be treated as the sum of predawn water potential $\left(\Psi_{\mathrm{wpd}}\right.$, base water potential) and diurnal depression from the base level $\left(\Psi_{\mathrm{d}}\right.$, depression potential): $\Psi_{\text {wmd }}=\Psi_{\text {wpd }}+\Psi_{\mathrm{d}}$ (Hinckley and Ritchie 1973; Lassoie et al. 1983; Pothier et al. 1989; Sellin 1998). $\Psi_{\text {wpd }}$, measured before dawn, is determined by soil water availability and should express the static water stress; $\Psi_{\mathrm{d}}$, in comparison, is influenced by atmospheric conditions and plant hydraulic capacity indicating the level of dynamic water stress (Sellin 1998).

Species can be partitioned into two categories across the continuum of stomatal regulation of water status, named isohydric and anisohydric regulation (Tardieu 1993; Tardieu and Simonneau 1998; McDowell et al. 2008). Isohydric plants maintain a relatively constant midday water potential $\left(\Psi_{w m d}\right)$ regardless of drought conditions due to reduced stomatal conductance, while anisohydric species 
allow midday values to decline as soil water potential decreases with drought (McDowell et al. 2008). Hence, anisohydric species maintain higher stomatal conductance for a given $\Psi_{\text {wmd }}$ than isohydric plants, effectively allowing $\Psi_{\text {wmd }}$ to decline with decreasing soil water availability (McDowell et al. 2008). By means of information about leaf water potentials, native tree species can be assigned to one of these two categories.

The osmotic potential $\left(\Psi_{\mathrm{s}}\right)$, in contrast, indicates the prime adaptation of plants towards spatially and periodically altered soil solute concentration and soil water deficit (Kramer and Boyer 1995; Mitloehner and Koepp 2007). Dehydration-tolerant species (according to the terminology of Kramer (1980)) reduced $\Psi_{\mathrm{s}}$ and/or accumulate solutes (osmotic adjustment; Morgan 1980) by incorporating ionic osmotica (i.e. $\mathrm{NaCl}$ among other salts from the soil) as well as by processing non-ionic osmotica (i.e. other plant-born organic compounds such as sucrose) into and within their cells (Mitloehner and Koepp 2007) reflecting plant adjustment to water shortage at the cell level. In this way, a plants' capacity to take up water from dry soils is enhanced and recovery after drought is facilitated (Gebre et al. 1998; Tschaplinski et al. 1998; Nguyen-Queyrens et al. 2002). Osmotic and pressure-driven water flow into plant roots occur simultaneously (Kramer and Boyer 1995). Furthermore, an osmotic (or concentration) gradient in the soilplant continuum (Pressarakli 1991) and within the plant between its cells are a basic condition for plant life (Mitloehner and Koepp 2007).

Osmotic adjustment can be estimated by the difference between $\Psi_{\mathrm{s}}$ of well-hydrated and dehydrated plants at similar relative water content (Gebre et al. 1998). It is difficult to determine osmotic adjustment under ambient field conditions due to the need to sample well-hydrated and dehydrated plants during the same period. Therefore, studies of osmotic adjustment have been based rather on comparison of seasonal variation in $\Psi_{\mathrm{s}}$ due to difference in precipitation within a season or between seasons (Bahari et al. 1985; Abrams 1990; Gebre et al. 1998).

In general, a species' capacity of acclimatation to environmental site conditions is regarded as the basic requirement for a plants' 'suitability as an indicator' (Mitlöhner 1997). During the last two decades, the Mexican Government has made an effort to restore degraded forest areas, mainly using fast growing pines or introduced species. However, the conservation-oriented interest in native broad-leaved species is increasing lately, and information on their biology and silvics is urgently needed (Quintana-Ascencio et al. 2004).

Hence, the specific objectives of our study were to (1) compare three dominant tree species of mixed pine-oak forests in the Sierra Madre Oriental with respect to their acclimatation to water deficit and their salt tolerance scope;
(2) compare the effect of two different sites on the water status of the species and (3) identify their strategies to withstand periods of drought.

\section{Methods}

Site description

This research was carried out at the Experimental Forest Research Station of the Faculty of Forest Science, Universidad Autónoma de Nuevo León (UANL) in the

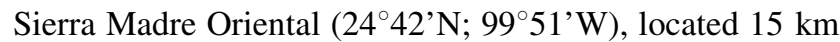
southeast of Iturbide in the state of Nuevo Leon, Mexico. The Experimental Forest Research Station extends over an area of about 1,035 ha and due to its protection status received 20 years ago, it provides good conditions for the study of undisturbed ecophysiological processes. Two sites in different pine-oak forests were selected for the study: (1) a major closed stand on a North-facing aspect (Plot-N) at $356^{\circ}$ and with $26^{\circ}$ inclination and (2) an open fragmented stand on a South-facing aspect (Plot-S) at $135^{\circ}$ and with $21^{\circ}$ inclination. Both sites are located from each other in a distance of about $200 \mathrm{~m}$ on the same mountain ridge at an elevation of approximate 1,600 $\mathrm{m}$. The mean annual air temperature is $13.9^{\circ} \mathrm{C}$ and the average annual precipitation is $639 \mathrm{~mm}$, which is concentrated from May to October. The dominant soils are rocky and comprise upper cretaceous lutite or siltstone (Cantú and González 2002). Some physical and chemical properties of the soil at profile depths of $0-10$ and $20-30 \mathrm{~cm}$ are shown in Table 1. Remarkable is the higher electric conductivity $\left(\mu \mathrm{Scm}^{-1}\right)$ at soil depth $0-10 \mathrm{~cm}$ compared to layer $20-30 \mathrm{~cm}$ and the slightly higher values at the northern in comparison to the southern aspect.

Sampling procedures and water potential measurement

In each sampling plot, five juvenile individuals (replications) of each tree species were randomly selected within a $500 \mathrm{~m}^{2}$ circle from the understory for repetitive measurements of plant water potentials. The plant species were Juniperus flaccida Schltdl. (Cupressaceae), P. pseudostrobus Lindl. (Pinaceae) and $Q$. canbyi Trel. (Fagaceae). Sampling trees varied in mean diameter at breast height between $2.05 \pm 0.33$ and $3.07 \pm 0.55 \mathrm{~cm}$, and in mean height between $2.70 \pm 0.32$ and $3.85 \pm 0.44 \mathrm{~m}$, depending on the species. The leaf water potentials $\left(\Psi_{\mathrm{w}}, \mathrm{MPa}\right)$ were determined twice a month from January until August 2006 , and leaf osmotic potentials $\left(\Psi_{\mathrm{s}}\right.$, MPa) were measured once a month during the same period. Plant water potentials were measured with a Scholander pressure chamber (Model 3005, Soil Moisture Equipment Corp., 
Table 1 Some physical and chemical soil properties at the two study sites (North and South aspect)

\begin{tabular}{llllllrrr}
\hline Sampling site & Soil profile depths $(\mathrm{cm})$ & Bulk density $\left(\mathrm{Mg} \mathrm{m}^{-3}\right)$ & $\mathrm{Sand}^{\mathrm{a}} \%$ & Silt $^{\mathrm{b}} \%$ & Clay $^{\mathrm{c}} \%$ & $\mathrm{pH}$ & $\mathrm{EC}\left(\mu \mathrm{Scm}{ }^{-1}\right)$ & $\mathrm{OM}^{(\%)}$ \\
\hline Plot-N & $0-10$ & 0.69 & 25.9 & 47.6 & 26.6 & 7.6 & 159.2 & 11.4 \\
Plot-N & $20-30$ & $\mathrm{ND} *$ & 12.6 & 39.3 & 48.1 & 7.7 & 75.9 & 2.7 \\
Plot-S & $0-10$ & 0.85 & 30.0 & 41.6 & 26.4 & 7.6 & 141.8 & 11.3 \\
Plot-S & $20-30$ & ND* & 39.6 & 43.8 & 16.6 & 7.7 & 72.1 & 2.5 \\
\hline
\end{tabular}

Each value is the mean of five replications

$E C$ electric conductivity, $O M$ organic material

* ND no data available

a Soil particle size: $0.063-2.0 \mathrm{~mm}$

b Soil particle size: $0.002-0.063 \mathrm{~mm}$

${ }^{c}$ Soil particle size: $<0.002 \mathrm{~mm}$

Santa Barbara, CA, USA) (Scholander et al. 1965) immediately after cutting the leaves or terminal twigs of each sample tree and monitored twice a day, at 6:00 h $\left(\Psi_{\text {wpd }}\right)$ and 12:00 h $\left(\Psi_{\text {wmd }}\right)$, which is a widely used method (Sellin 1996). For safety reasons, and per operating instructions, the lowest limit of the pressure chamber was -7.3 MPa.

For determination of the osmotic potential $\left(\Psi_{\mathrm{s}}, \mathrm{MPa}\right)$, plant samples were taken with a hole puncher from leaves of $Q$. canbyi. In the case of J. flaccida and P. pseudostrobus, parts of photosynthetic twigs and pine needles were cut, respectively. Plant samples were collected at 6:00 h ( $\left(\Psi_{\mathrm{spd}}\right)$ and 12:00 h $\left(\Psi_{\mathrm{smd}}\right)$ and immediately saved in small tubes and shock-frozen in liquid nitrogen to conserve them for later laboratorial analysis. Once in the laboratory, the osmotic potential of leaf tissues was assessed with a thermocouple psychrometer using three Wescor C-52 sample chambers and an HR 33T microvoltmeter (Wescor Inc., Logan, UT) calibrated at $25^{\circ} \mathrm{C}$ and standardised with $50 \mu \mathrm{l}$ of known $\mathrm{NaCl}$ molal solutions (Wilson et al. 1979).

\section{Environmental data}

Simultaneously, meteorological data of air temperature $\left({ }^{\circ} \mathrm{C}\right)$ and relative humidity $(\%)$ was registered in each plot on an hourly basis by using a thermo-hygrometer $\left(\mathrm{HOBO}^{\circledR}\right.$ Pro Series Weatherproof Data Loggers, Forestry Suppliers, USA) that was located between the sampling trees directly in the sampling site $1.5 \mathrm{~m}$ above ground in the understory. Likewise, daily precipitation $(\mathrm{mm})$ was obtained from selfemptying rain gauges $\left(\right.$ Onset $^{\circledR}$ Data Logging Rain Gauge, Forestry Suppliers, USA) installed $1.5 \mathrm{~m}$ above ground at an open place close to each plot. Vapour pressure deficit (VPD) was calculated on the basis of air temperature and relative air humidity $(\mathrm{RH})$. On each sampling date, soil cores at different depths of $0-10,20-30,40-50$, and 60-70 cm (five replications each) were collected using a soil sampling tube (Soil Moisture Equipment Corp.) for determining the gravimetric soil water content beneath the tree canopy in each plot. The soil water content was finally determined and expressed in per cent by weight (\%).

Statistical analysis

The desire was to test the null hypothesis of no effect of tree species, site and sampling date on the water potentials (leaf $\Psi_{\mathrm{w}}$ and leaf $\Psi_{\mathrm{s}}$ each at predawn and midday) of common species in pine-oak forests in the Sierra Madre Oriental.

Differences between the two aspects ( $\mathrm{N}$ and $\mathrm{S})$, the tree species and the sampling dates (January to August 2006) were examined with three-way analyses of variance (threeway ANOVA), while aspect and species were considered as between-subject factors and sampling date (sd) as within-subject factor (Zar 1999). The three-way ANOVA was conducted for predawn and midday data separately. Assumption of normality and homogeneity of variance was tested before ANOVA and found as true.

Differences between meteorological conditions at each aspect were compared by one-way ANOVA after proofing true the assumption of normality and homogeneity of variance (Zar 1999; Crawley 2007).

The significance of seasonal differences $(\Delta \mathrm{SD})$ in $\Psi_{\text {spd }}$ and $\Psi_{\text {smd }}$ was tested with the Wilcoxon's rank sum test (Crawley 2007), comparing a representative dry (Apr-5) and moist (Aug-16/17) sampling date.

Correlation coefficients between water and osmotic potentials ( $\Psi_{\text {wpd, }} \Psi_{\text {wmd, }} \Psi_{\text {spd }}$ and $\left.\Psi_{\text {smd }}\right)$ and environmental variables (monthly sum of precipitation, daily mean soil water content, daily mean air temperature, daily mean $\mathrm{RH}$ and daily mean VPD, each recorded on the sampling date) were quantified by the Spearman's rank order correlation analyses, since the null hypothesis of normality was rejected at $P<0.05$. For these analyses, real data of each species, summarizing both plots, were considered on a seasonal base (Zar 1999; Crawley 2007). 
On a seasonal basis, regression analysis was performed between averaged soil water content and predawn leaf water potentials $\left(\Psi_{\text {wpd }}\right)$ considering mean values of each sampling date (Crawley 2007).

All statistical methods were applied according to the $\mathrm{R}$ project for statistical computing (free statistic software, $\mathrm{R}$ version 2.8.1, The R Foundation for Statistical Computing 2008).

\section{Results}

Environmental conditions during the experimental period

Trends of monthly mean air temperatures, relative air humidity, vapour pressure deficit, total precipitation and soil water content are illustrated in Fig. 1. Air temperature increased until April and decreased slightly until the end of the study period. Relative air humidity increased notably from April to August and vapour pressure deficit increased until April but decreased noticeably during the rest of the study period. The sum of precipitation increased in the course of the study. Concerning the total rainfall at the northern aspect, due to technical problems, the monthly rainfall in July had to be estimated by interpolation using registered precipitation of June and August. The comparison of the two sites revealed no statistical differences in meteorological variables (one-way ANOVA: $P>0.18$ ).

Averaged soil moisture content decreased along the growing season at both sites, but increased again after the onset of the rainy season in the end of May, especially in the upper soil horizons (Fig. 1). The results of the threeway ANOVA indicated that 'aspect' had the strongest influence on soil water content followed by 'sampling date' as shown by the proportion of explained variance (Table 2). In general, soil moisture content was significantly higher at the northern aspect than at the southern. In comparison, soil depths had no significant influence on soil water content. The ANOVAs demonstrated some significant interactions of factors (Table 2 and Fig. 1). Thus, soil moisture content at different soil depths is influenced by the season interpreting the strongest interaction 'depths $x$ sampling date'. The explained variation by the ANOVA model was not moderate (Table 2).

\section{Variation in leaf water potentials}

The results of the three-way ANOVA indicated that the 'sampling date' had the strongest influence on leaf water potential patterns followed by the between-factors 'species' and 'aspect'; see proportion of explained variance in Table 2. Both variables ( $\Psi_{\text {wpd }}$ and $\Psi_{\text {wmd }}$ ) showed strong
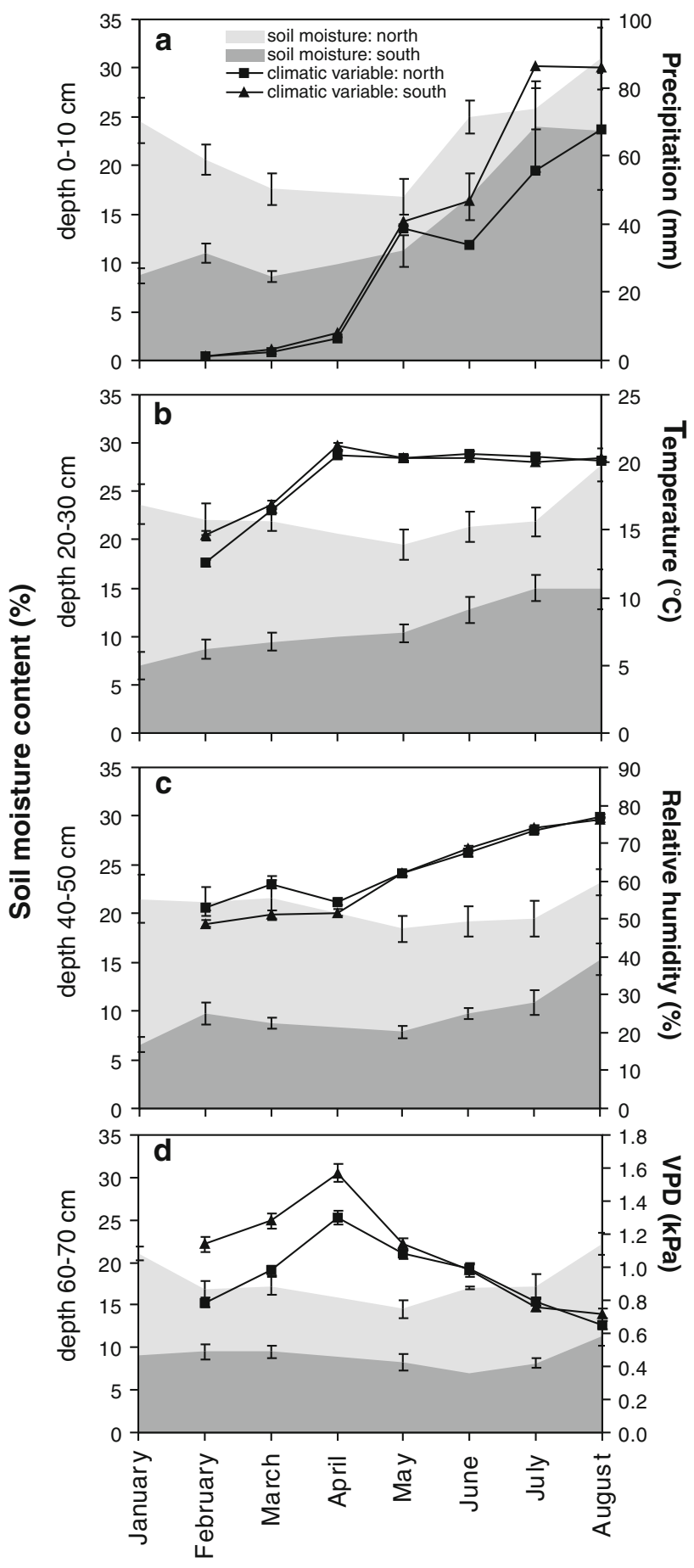

Month (2006)

Fig. 1 Seasonal variation in mean air temperature $\left({ }^{\circ} \mathrm{C}\right)$, relative humidity $(\%)$, vapour pressure deficit $(V P D ; \mathrm{kPa})$, actual precipitation $(\mathrm{mm})$ and mean soil moisture $(\%)$ at four soil profile depths $(n=5)$ during the study period from February until August 2006; bars represent standard errors

interactions of all factors (as demonstrated by the ANOVAs; Table 2 and Fig. 2), reflecting that the influence of 'sampling date' was highly significant on the species 
Table 2 Results of the three-way ANOVA with species (between-subject), aspect (between-subject) and sampling date (within-subject) as factors, degrees of freedom (df) and coefficient of determination $\left(r^{2}\right)$

\begin{tabular}{|c|c|c|c|c|c|c|c|c|c|c|c|c|c|}
\hline \multirow[t]{2}{*}{ Source of variation } & \multirow[b]{2}{*}{ df } & \multicolumn{2}{|l|}{$\Psi_{\mathrm{wpd}}$} & \multicolumn{2}{|l|}{$\Psi_{\text {wmd }}$} & \multirow[b]{2}{*}{ df } & \multirow[b]{2}{*}{$F$} & \multicolumn{2}{|l|}{$\Psi_{\text {spd }}$} & \multirow{2}{*}{$\begin{array}{l}\Psi_{\text {smd }} \\
\mathrm{SS}_{\mathrm{x}} / \mathrm{SST}_{\mathrm{c}}\end{array}$} & \multirow[b]{2}{*}{ df } & \multicolumn{2}{|c|}{ Soil moisture } \\
\hline & & $F$ & $\mathrm{SS}_{\mathrm{x}} / \mathrm{SST}_{\mathrm{c}}$ & $F$ & $\mathrm{SS}_{\mathrm{x}} / \mathrm{SST}_{\mathrm{c}}$ & & & $\mathrm{SS}_{\mathrm{x}} / \mathrm{SST}_{\mathrm{c}}$ & $F$ & & & $F$ & $\mathrm{SSx} / \mathrm{SSTc}$ \\
\hline Species $^{\mathrm{a}}$ & 2 & 137.9 & $13.8 * * *$ & 76.7 & $14.7 * * *$ & 2 & 9.3 & $6.5^{* * *}$ & 11.3 & $7.3 * * *$ & 2 & 1.9 & $1.8^{\mathrm{NS}}$ \\
\hline Aspect & 1 & 210.4 & $10.5 * * *$ & 164.1 & $15.7 * * *$ & 1 & 14.9 & $5.2 * * *$ & 3.0 & $1.0^{\mathrm{NS}}$ & 1 & 86.7 & $38.3^{*}$ \\
\hline Aspect*Species & 2 & 6.8 & $0.7 * *$ & 6.9 & $1.3 * *$ & 2 & 2.3 & $1.6^{\mathrm{NS}}$ & 2.9 & $1.9^{\mathrm{NS}}$ & 2 & 9.1 & $0.9 * * *$ \\
\hline $\mathrm{SD}^{\mathrm{b}}$ & 11 & 144.3 & $38.4 * * *$ & 77.8 & $30.7 * * *$ & 6 & 14.9 & $22.2 * * *$ & 9.9 & $17.2 * * *$ & 10 & 4.5 & $13.9 * *$ \\
\hline Species*SD & 22 & 22.7 & $12.1 * * *$ & 16.9 & $13.3 * * *$ & 12 & 3.4 & $10.2 * * *$ & 2.1 & $7.3^{*}$ & 20 & 6.1 & $5.9 * * *$ \\
\hline Aspect*SD & 11 & 39.8 & $10.6 * * *$ & 19.4 & $7.7 * * *$ & 6 & 4.0 & $5.9 * * *$ & 4.8 & $8.4 * * *$ & 10 & 6.3 & $3.3 * * *$ \\
\hline Aspect*Species*SD & 22 & 12.0 & $6.4 * * *$ & 6.1 & $4.8 * * *$ & 12 & 1.5 & $4.3^{\mathrm{NS}}$ & 2.1 & $7.4^{*}$ & 20 & 0.3 & $0.9^{\mathrm{NS}}$ \\
\hline Total & 359 & & & & & 209 & & & & & & & \\
\hline ANOVA $r^{2}$ (adj.) & & & 0.913 & & 0.871 & & & 0.483 & & 0.393 & & & 0.555 \\
\hline
\end{tabular}

The $F$-value, proportion of the explained variance $\left(\mathrm{SS}_{\mathrm{x}} / \mathrm{SST}_{\mathrm{c}}\right)$ and the level of significance $(N S, P>0.05 ; * P<0.05 ; * * P<0.01 ; * * *$ $P<0.001)$ for each factor and the interaction are indicated

a In the case of soil moisture, the factor 'species' is replaced by 'soil depth'; ${ }^{\mathrm{b}}$ Sampling date

J. flaccida and Q. canbyi but less on P. pseudostrobus. Or, that the influence of 'sampling date' was highly significant on the water potentials measured at Plot-S and less at Plot-N (Table 2 and Fig. 2). The explained variation by the ANOVA model was high (mean 0.89, range 0.87-0.91).
Fig. 2 Seasonal variation in predawn $\left(\Psi_{\text {wpd }}\right)$ and midday $\left(\Psi_{\text {wmd }}\right)$ leaf water potentials as well as the difference between midday and predawn $\left(\Delta \Psi_{\mathrm{w}}\right)$ leaf water potentials in three tree species at the North (Plot-N) and South aspect (Plot-S); values are means $(n=5)$, bars represent standard error
Plot-N

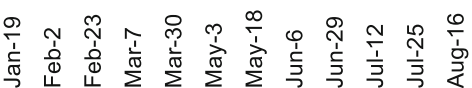
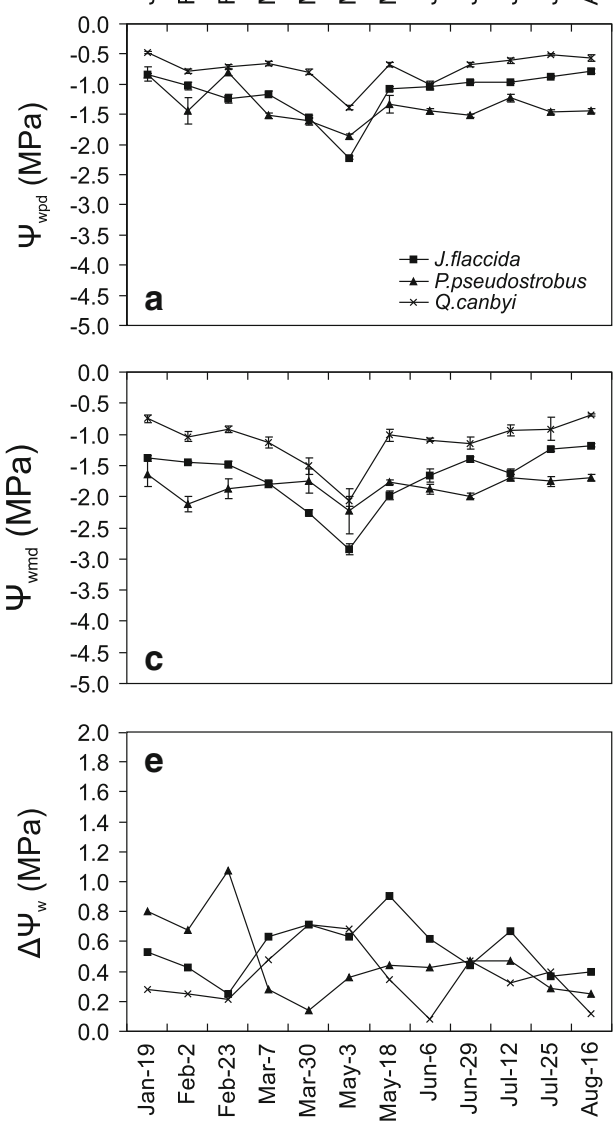

Sampling date (month-day: 2006)
Plot-S
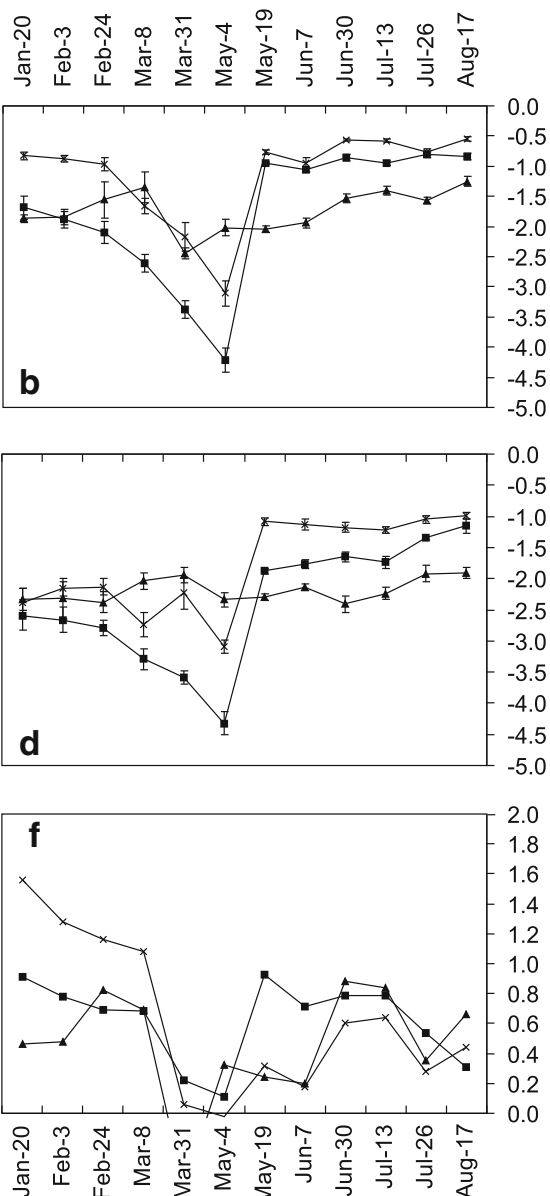
In general, $Q$. canbyi had the highest predawn and midday leaf water potentials at the northern aspect throughout the study period (Fig. 2a, c). At the southern site, in comparison, $P$. pseudostrobus maintained highest values during the dry period from March to May, but was topped by $Q$. canbyi and J. flaccida after the onset of precipitation (Fig. 2b, d). J. flaccida showed most negative values in both study sites and highest seasonal variation.

Furthermore, water stress appeared earlier in Plot-S than in Plot-N. In Plot-S for instance, $\Psi_{\text {wpd }}$ began to decline drastically in early March and in Plot-N towards the end of March. Midday leaf water potentials were more negative but with similar tendencies as observed in predawn potentials (Fig. 2c, d). Moreover, tree species suffered less water stress in Plot-N (Fig. 2e) than in Plot-S (Fig. 2f), where $\Delta \Psi_{\mathrm{w}}$ were close to zero for all species on Mar-31 and May-4.

Variation in leaf osmotic potentials

Leaf osmotic potentials were mainly influenced by 'sampling date' and further by 'species' and 'aspect' as the results of the three-way ANOVA indicated (Table 2). Both variables ( $\Psi_{\text {spd }}$ and $\Psi_{\text {smd }}$ ) showed some significant interactions of factors (as demonstrated by the ANOVAs; Table 2 and Fig. 3). For instance, the influence of 'sampling date' was highly significant on $\Psi_{\text {spd }}$ of the species J. flaccida and Q. canbyi but less of P. pseudostrobus, and in the case of $\Psi_{\text {smd }}$ it was highly significant on the water potentials measured at Plot-S and less at Plot-N (Table 2 and Fig. 2). The explained variation by the ANOVA model was not as high (mean 0.44, range 0.39-0.48) as for leaf water potentials.

In general, midday osmotic potentials were more negative (Fig. 3c, d). Concerning the site comparison, osmotic potentials were much lower at the southern aspect (Fig. 3b, d) than at the northern (Fig. 3a, c). Compared to leaf water potentials, osmotic potentials differed less between species and in time. In Plot-S (Fig. 3d), where differences between species were a little greater, $P$. pseudostrobus maintained generally higher osmotic potentials than $Q$. canbyi and J. flaccida. Nevertheless, with increasing water supply at the end of the study period (Fig. 1), the osmotic potentials of the three species draw near (Fig. 3).
Fig. 3 Seasonal variation in predawn $\left(\Psi_{\text {spd }}\right)$ and midday $\left(\Psi_{\text {smd }}\right)$ osmotic potential in three tree species at the North (Plot-N) and South aspect (Plot-S); values are means $(n=5)$, bars represent standard error

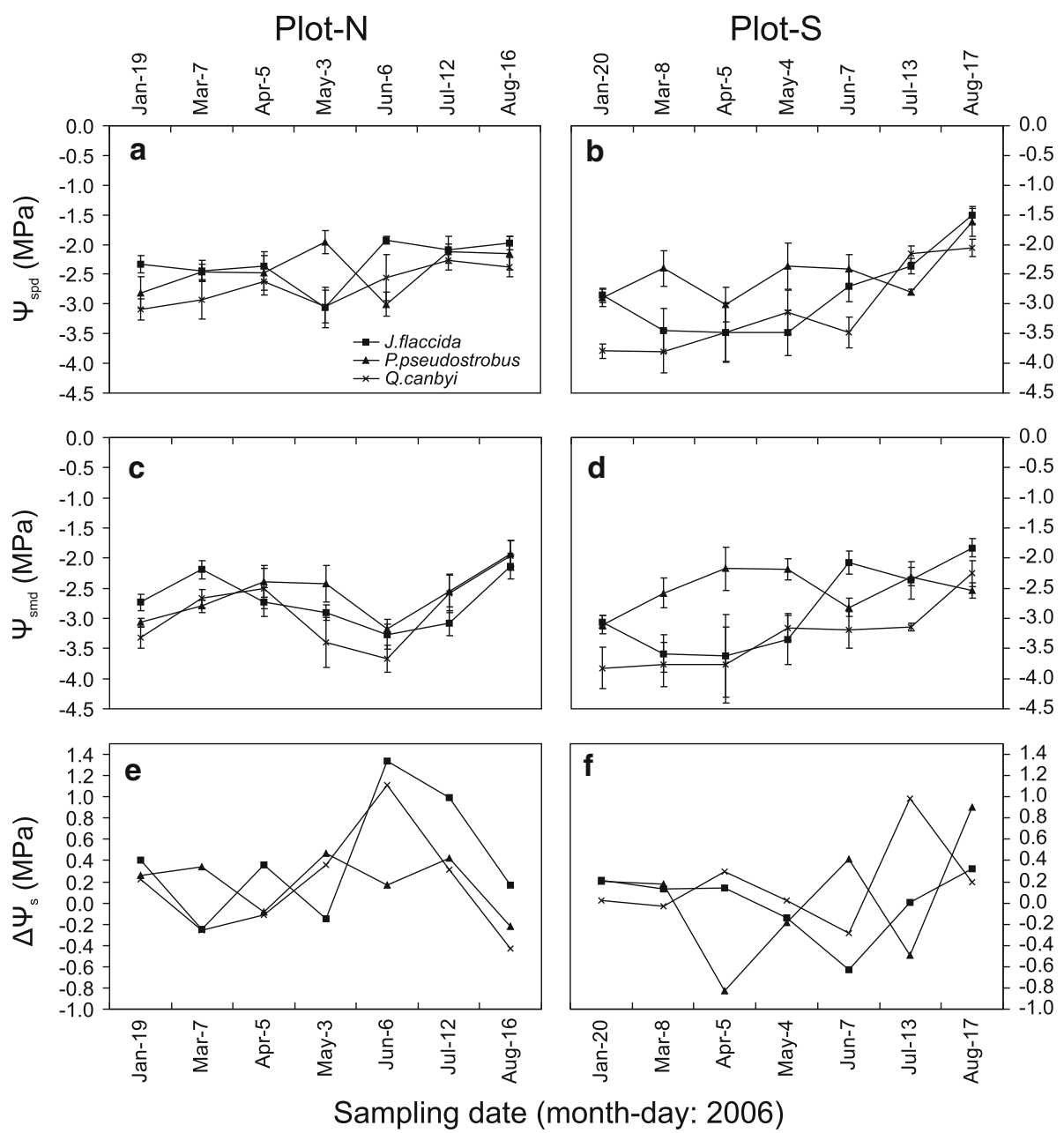


Concerning the $\Delta \Psi_{\mathrm{s}}$, it is difficult to see a clear tendency, especially for $P$. pseudostrobus (Fig. 3e, f) In the case of J. flaccida and $Q$. canbyi, $\Delta \Psi_{\mathrm{s}}$ had wide ranges during the moist and small ranges during the dry period (Apr-5) in Plot-N (Fig. 3e). In Plot-S in comparison, $Q$. canbyi and $J$. flaccida had relatively wide $\Delta \Psi_{\mathrm{s}}$ during the dry period (Fig. 3f). Here, the major decrease in $\Delta \Psi_{\mathrm{s}}$ was observed later (Jun-7) recovering wider ranges again in August.

Seasonal differences $(\Delta \mathrm{SD})$ in osmotic potentials $\left(\Psi_{\text {spd }}\right.$ and $\Psi_{\text {smd }}$ ) between a representative dry (Apr-5) and moist (Aug-16/17) sampling date were significant for all species concerning $\Psi_{\text {spd }}(P<0.01)$, while $\Psi_{\text {smd }}$ were significantly different only for $J$. flaccida $(\Delta \mathrm{SD}=1.19 \mathrm{MPa} ; P<0.01)$ and $Q$. canbyi $(\Delta \mathrm{SD}=1.03 \mathrm{MPa} ; P<0.05)$.

Relationships between plant water potentials and environmental variables

Correlations between environmental variables and predawn water and osmotic potentials ( $\Psi_{\text {wpd }}$ and $\left.\Psi_{\text {spd }}\right)$ as well as the diurnal depression of both, water and osmotic potentials, are shown in Table 3. In general, highly significant $(P<0.05)$ and positive correlations were found between leaf water potentials $\left(\Psi_{\text {wpd }}\right)$ and soil water content, whereas correlations were strongest within the first three soil depths. Concerning the meteorological variables, correlations of $\Psi_{\text {wpd }}$ were strongest with daily mean relative air humidity (RH) (Table 3) and to a lesser extent with daily vapour pressure deficit (VPD), monthly precipitation and daily mean air temperature.

Similar tendencies as in water potentials were observed in osmotic potentials $\left(\Psi_{\text {spd }}\right)$. Nevertheless, osmotic potentials of $P$. pseudostrobus were not correlated with environmental variables (Table 3). J. flaccida and $Q$. canbyi in comparison showed significantly strong correlations with soil water content and daily mean relative air humidity $(P<0.001)$.

In the case of the conifers, diurnal depression of leaf water potentials was significantly $(P<0.05)$ correlated with the meteorological variables RH and VPD reflecting mainly the air water status (Table 3). The depression potential of the broad-leaved species $Q$. canbyi in comparison had strong correlations with soil water content, daily mean air temperature and monthly sum of precipitation reflecting rather soil water status (Table 3). Concerning the diurnal depression of leaf osmotic potentials, just one significant correlation with daily mean air temperature was found for J. flaccida.

Fig. 4 describes the relationship between soil water content and $\Psi_{\text {wpd }}$ for the three tree species. The averaged soil water content in the $0-70 \mathrm{~cm}$ soil depth profile explained between $(P<0.05) 24 \%$ ( $P$. pseudostrobus $)$ and $56 \%$ (J. flaccida) of the variation in $\Psi_{\mathrm{wpd}}$ (Table 4). Moreover, it was found that at gravimetric soil water content values above $15 \%, \Psi_{\text {wpd }}$ values were high and roughly constant; below this threshold value, water potentials declined gradually (Fig. 4).
Table 3 Spearman's correlation coefficient values $(r h o)$ for predawn potentials (PD) and diurnal depression (DD) of leaf water (observed data of both plots; $n=2$ aspect $\times 3$ species $\times 5$ replications $\times 11$ $\mathrm{SD}=330$ ) and osmotic potential (observed data of both plots; $n=2$ aspect $\times 3$ species $\times 5$ replications $\times 6 \mathrm{SD}=180)$ in relation to mean soil water content at four depths (SWC), daily mean air temperature, daily mean relative humidity $(\mathrm{RH})$ and daily mean vapour pressure deficit (VPD) and monthly sum of precipitation in three tree species (data of the sampling dates were used for the calculation of daily means)

\begin{tabular}{|c|c|c|c|c|c|c|c|c|c|c|c|c|}
\hline \multirow[t]{3}{*}{$\begin{array}{l}\text { Environmental } \\
\text { variable }\end{array}$} & \multicolumn{6}{|c|}{ Water potential at predawn (PD) and diurnal depression (DD) } & \multicolumn{6}{|c|}{$\begin{array}{l}\text { Osmotic potential at predawn (PD) and diurnal depression } \\
\text { (DD) }\end{array}$} \\
\hline & \multicolumn{2}{|l|}{ J. flaccida } & \multicolumn{2}{|c|}{ P. pseudostrobus } & \multicolumn{2}{|l|}{ Q. canbyi } & \multicolumn{2}{|l|}{ J. flaccida } & \multicolumn{2}{|c|}{ P. pseudostrobus } & \multicolumn{2}{|l|}{ Q. canbyi } \\
\hline & PD & DD & PD & DD & PD & DD & PD & DD & PD & DD & PD & DD \\
\hline SWC: $0-10 \mathrm{~cm}$ & $0.79 * * *$ & $0.14^{\mathrm{NS}}$ & $\mathbf{0 . 5 3} * * *$ & $-0.14^{\mathrm{NS}}$ & $0.71 * * *$ & $\mathbf{0 . 3 5} * * *$ & $\mathbf{0 . 7 0} * * *$ & $-0.15^{\mathrm{NS}}$ & $0.10^{\mathrm{NS}}$ & $-0.05^{\mathrm{NS}}$ & $0.66 * * *$ & $-0.08^{\mathrm{NS}}$ \\
\hline $\begin{array}{l}\text { SWC: } \\
20-30 \mathrm{~cm}\end{array}$ & $0.48 * * *$ & $0.17^{\mathrm{NS}}$ & $0.44 * * *$ & $0.01^{\mathrm{NS}}$ & $0.53 * * *$ & $0.40 * * *$ & $0.54 * * *$ & $-0.09^{\mathrm{NS}}$ & $0.09^{\mathrm{NS}}$ & $-0.13^{\mathrm{NS}}$ & $0.39 * *$ & $0.14^{\mathrm{NS}}$ \\
\hline $\begin{array}{l}\text { SWC: } \\
\quad 40-50 \mathrm{~cm}\end{array}$ & $0.40 * * *$ & $0.07^{\mathrm{NS}}$ & $0.38 * * *$ & $0.03^{\mathrm{NS}}$ & $0.45 * * *$ & $0.30 * *$ & $0.52 * * *$ & $-0.08^{\mathrm{NS}}$ & $0.06^{\mathrm{NS}}$ & $-0.10^{\mathrm{NS}}$ & $0.34 *$ & $0.17^{\mathrm{NS}}$ \\
\hline $\begin{array}{l}\text { SWC: } \\
\quad 60-70 \mathrm{~cm}\end{array}$ & $0.21 *$ & $0.15^{\mathrm{NS}}$ & $0.35 * * *$ & $0.08^{\mathrm{NS}}$ & $0.25^{*}$ & $0.24^{*}$ & $\mathbf{0 . 5 0} * * *$ & $-0.20^{\mathrm{NS}}$ & $0.12^{\mathrm{NS}}$ & $-0.15^{\mathrm{NS}}$ & $0.31 *$ & $0.19^{\mathrm{NS}}$ \\
\hline Temperature & $0.25 * *$ & $0.13^{\mathrm{NS}}$ & $-0.08^{\mathrm{NS}}$ & $0.24 *$ & $0.14^{\mathrm{NS}}$ & $0.31 * *$ & $0.37 * *$ & $-0.26^{*}$ & $-0.02^{\mathrm{NS}}$ & $0.07^{\mathrm{NS}}$ & $\mathbf{0 . 3 5} * *$ & $-0.06^{\mathrm{NS}}$ \\
\hline RH & $0.42 * * *$ & $0.24 *$ & $\mathbf{0 . 3 2} * * *$ & $-0.21 *$ & $0.38 * * *$ & $0.07^{\mathrm{NS}}$ & $0.42 * * *$ & $-0.13^{\mathrm{NS}}$ & $0.24^{\mathrm{NS}}$ & $-0.09^{\mathrm{NS}}$ & $\mathbf{0 . 5 0} * * *$ & $-0.11^{\mathrm{NS}}$ \\
\hline VPD & $-0.31 * * *$ & $-0.22 *$ & $-0.41 * * *$ & $0.29 * *$ & $-0.33 * * *$ & $-0.02^{\mathrm{NS}}$ & $-0.21^{\mathrm{NS}}$ & $0.11^{\mathrm{NS}}$ & $-0.12^{\mathrm{NS}}$ & $-0.06^{\mathrm{NS}}$ & $-0.30 *$ & $0.11^{\mathrm{NS}}$ \\
\hline Precipitation & $0.53 * * *$ & $-0.05^{\mathrm{NS}}$ & $-0.04^{\mathrm{NS}}$ & $0.03^{\mathrm{NS}}$ & $\mathbf{0 . 3 0} * *$ & $0.24 *$ & $0.23^{\mathrm{NS}}$ & $0.07^{\mathrm{NS}}$ & $0.20^{\mathrm{NS}}$ & $-0.01^{\mathrm{NS}}$ & $\mathbf{0 . 3 5} * *$ & $-0.14^{\mathrm{NS}}$ \\
\hline
\end{tabular}

Significant correlations are emphasised with bold letters

Due to missing meteorological data in January, the first sampling date was not included in the correlation analysis. Level of significance $(P>0.05$, NS; $* P<0.05 ; * * P<0.01 ; * * * P<0.001)$ for each variable 


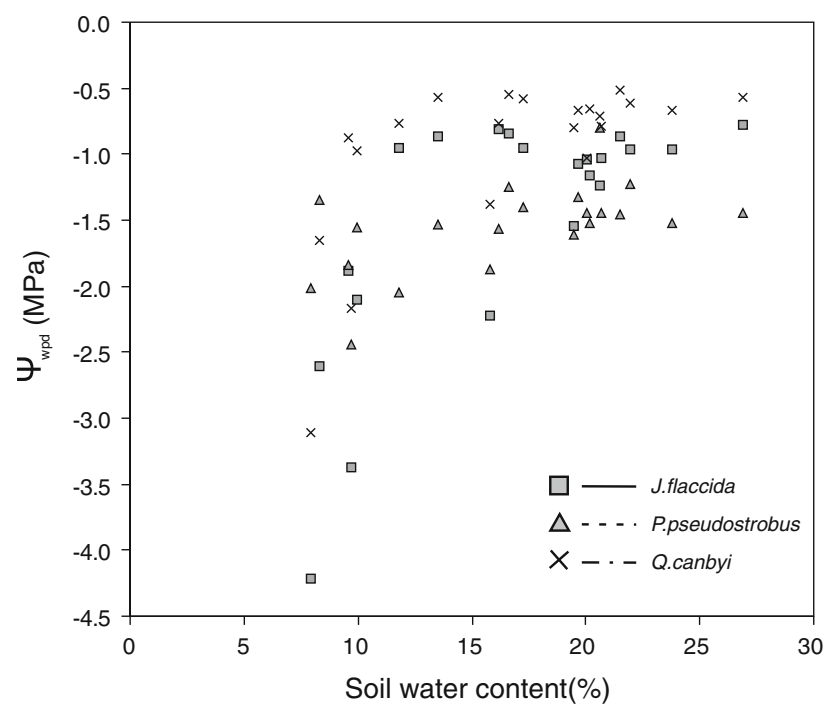

Fig. 4 Predawn $\left(\Psi_{\text {wpd }}\right)$ leaf water potentials of three native tree species as a function of the averaged gravimetric soil water content in the $0-70 \mathrm{~cm}$ soil layer

\section{Discussion}

Diurnal water potential values studied in the course of 8 months revealed significant differences between the two study sites, among species, and in the course of time, owing to which species seem to employ different strategies to offset the harmful effect of drought periods. An understanding of these strategies is of importance for the selection of suited tree species for future reforestation of drought-prone areas (Gebrekirstos et al. 2006).

All species presented their highest values at predawn and their lowest during midday, the value that integrates and reflects all environmental influences on the plants' internal water balance, indicating the least favourable condition for the plant (Gebre et al. 1998). The water potential of a fully hydrated plant may be close to zero, while water potentials could reach as low as $-12 \mathrm{MPa}$ under extreme water stress conditions in the field (Zunzunegui et al. 2005).

A plant can make up its water deficit during the night, that is why many authors consider $\Psi_{\text {wpd }}$ values as a true equilibrium of soil water potential (not measured in the present study) and plant water status (Mitlöhner 1997; Sellin 1999; Bucci et al. 2004). Furthermore, minimum $\Psi_{\text {wpd }}$ values are considered to express the static water stress (Sellin 1998). Nevertheless, some authors report that predawn potentials do not necessarily equilibrate with soil water potentials, especially under well-watered conditions and particularly for woody plants (Sellin 1999; Donovan et al. 2001; Bucci et al. 2004). In the present study, $\Psi_{\text {wpd }}$ of all species (Fig. 2) seemed to correspond to seasonal variation in soil water content (Fig. 1) as the strong correlations and regression analyses indicate (Tables 3, 4), although values of $P$. pseudostrobus showed less fluctuations. However, data of all sampling dates were pooled and results might be different analyzing the relationship between soil water content and $\Psi_{\text {wpd }}$ for each sampling date separately.

The midday water potential $\left(\Psi_{\text {wmd }}\right)$ can be split into the base water potential $\left(\Psi_{\mathrm{wpd}}\right)$ and diurnal depression $\left(\Psi_{\mathrm{d}}\right)$ which is mainly influenced by atmospheric conditions and plant hydraulic capacity, indicating the level of dynamic water stress (Hinckley and Ritchie 1973; Lassoie et al. 1983; Pothier et al. 1989; Sellin 1998). This was clearly confirmed by the results of the correlation analysis which presented significant correlations between $\Psi_{\mathrm{d}}$ and daily mean relative air humidity, and daily mean vapour pressure deficit in the case of the two conifers. Diurnal depression of Q. canbyi in contrast, was significantly correlated with soil water content (Table 3 ) reflecting the species' dependence on soil water content.

J. flaccida showed highest seasonal fluctuations and presented the lowest minimum values at both sites. P. pseudostrobus in comparison presented more balanced values in the course of the study, especially under the drier soil condition in Plot-S. Since isohydric plants reduce

Table 4 Least-squares coefficients for predawn leaf water potential $\left(\Psi_{\mathrm{wpd}}\right)$ in relation to averaged soil water content (ASWC) in three tree species

\begin{tabular}{|c|c|c|c|c|c|c|c|}
\hline \multirow[t]{3}{*}{ Tree species } & \multicolumn{7}{|c|}{ Least-squares statistics } \\
\hline & \multicolumn{3}{|c|}{$Y$-axis intercept } & \multicolumn{3}{|c|}{ Slope of regression model } & \multirow[t]{2}{*}{ Adjusted $r^{2}$} \\
\hline & $\hat{\beta}_{0}$ & E.S.E. & $P$ value & $\hat{\beta}_{1}$ & E.S.E. & $P$ value & \\
\hline J.flaccida & 3.13 & 0.56 & $<0.001$ & -1.04 & 0.20 & $<0.001$ & 0.56 \\
\hline P. pseudostrobus & 1.32 & 0.33 & $<0.001$ & -0.33 & 0.12 & $<0.05$ & 0.25 \\
\hline Q. canbyi & 2.43 & 0.57 & $<0.002$ & -0.94 & 0.20 & $<0.001$ & 0.50 \\
\hline
\end{tabular}

Least-squares estimates have indicated that the best fitted model to relate $\Psi_{\text {wpd }}$ as a function of averaged soil water content corresponded to a power mathematical function $\left(\hat{\Psi}_{w p d}=\hat{\beta} \times A S W C^{\hat{\beta}_{1}}\right.$, where $\left.\hat{\Psi}_{w p d}=-\Psi_{w p d}\right) . \hat{\beta}_{0}$ and $\hat{\beta}_{1}$ are the $y$-axis intercept and slope of the regression model, respectively. Estimated standard errors (E.S.E.'s), $P$ values and adjusted coefficient of determination $\left(r^{2}\right)$ values are provided; $n=22$ 
stomata conductance as soil water content declines and atmospheric conditions dry, they maintain relative constant $\Psi_{\text {wmd }}$ values regardless of drought conditions. Hence, $P$. pseudostrobus presented a typical pattern of isohydric water regulation, while J. flaccida was identified as an anisohydric species that maintain higher stomata conductance and allow $\Psi_{\text {wmd }}$ to decline with decreasing soil water content (Tardieu and Simonneau 1998; McDowell et al. 2008). Also other authors mention pine species (Pinus edulis) as good examples for isohydric regulation (Lajtha and Barnes 1991; Williams and Ehleringer 2000; West et al. 2008; Breshears et al. 2009) and identified juniper (Juniperus monosperma) as an anisohydric species (Loewenstein and Pallardy 1998a, b; Tardieu and Simonneau 1998; Franks et al. 2007; West et al. 2008; Breshears et al. 2009). The course of seasonal $\Psi_{\text {wmd }}$ of $Q$. canbyi indicated rather anisohydric water status regulation, since fluctuations of $\Psi_{\text {wmd }}$ values corresponded to soil water availability and were very similar to those of J. flaccida varying notably over time. Though, in literature several oak species are recognised to regulate efficiently their water status during drought by reduced stomata conductance (Gallego et al. 1994; Cochard et al. 1996; Morecroft and Roberts 1999; Kolb and Stone 2000; Xu and Baldocchi 2003; Otieno et al. 2007) that rather suggests isohydric water status regulation. Nevertheless, $Q$. canbyi apparently lost water under dry conditions as the course of $\Psi_{\text {wmd }}$ values indicate (Fig. 2) and therefore seems to exhibit anisohydric behaviour.

In contrast to isohydric species, anisohydric species tend to occur more in drought-prone habitats (McDowell et al. 2008) like J. flaccida which inhabits mostly xeric areas. McDowell et al. (2008) discuss various hypotheses on mechanisms of drought related plant mortality and present a theoretical relationship between duration and intensity of (water) stress and the three hypothetical mechanisms of mortality: biotic agent demographics, hydraulic failure and carbon starvation. The type of water status regulation, anisohydric versus isohydric, may be a critical factor for plant survival and mortality during drought (McDowell et al. 2008).

Usually one expects to observe higher water potentials at predawn than at midday and a wide range or positive values of $\Delta \Psi_{\mathrm{w}}$ indicate a high degree of plasticity or high physiological capacity to regulate water loss and maintain high $\Psi_{\mathrm{w}}$ (Mitlöhner 1998; Gebrehiwot et al. 2005). This was the case for J. flaccida which presented the widest $\Delta \Psi_{\mathrm{w}}$ under severe drought conditions (Fig. 2e). Conversely, narrow $\Delta \Psi_{\mathrm{w}}$ or even negative values during dry periods, as were found for $P$. pseudostrobus and $Q$. canbyi, indicate a lack of species' capacity to re-saturate during the night (González et al. 2004; Gebrehiwot et al. 2005; Gebrekirstos et al. 2006).
Nevertheless, Sellin (1998) reported that the sensitivity of trees' water status to the atmospheric evaporative demand depended on soil water availability. Furthermore, under drought conditions, more negative predawn values ( $\Psi_{\text {wpd }}$ ) can be observed in comparison to midday $\Psi_{\text {wmd }}$ as a consequence of stomata closure, solute enriched xylem concentration, or rather osmotic adjustment (Sellin 1998; Donovan et al. 2003). Similarly, it has been documented for several plant species that stomata do not close completely at night, allowing nocturnal transpiration and thus preventing soil-plant water potential equilibration during night (Kavanagh et al. 2007). Whether or not this mechanism influenced the predawn water potentials responses in studied species remains unknown. However, the trends observed in $P$. pseudostrobus and $Q$. canbyi open a research line for these hypotheses.

Osmotic potentials ( $\Psi_{\text {spd }}$ and $\Psi_{\text {smd }}$ ) decreased for all species parallel to the loss of soil moisture content in the course of the study until the onset of the summer precipitations. In general, seasonal declines in $\Psi_{\mathrm{s}}$ of mature leaves reported in several studies including various species, have been interpreted as a response to either drought, shoot or leaf age (see Gebre et al. 1998 for references). Since $\Psi_{\mathrm{s}}$ were always measured on mature leaves or shoots of trees, the decline in $\Psi_{\mathrm{s}}$ is interpreted as water stress. Low osmotic potentials during drought periods indicate higher drought tolerance (Morgan 1984; Aranda et al. 1996; Gebre et al. 1998; Aranda et al. 2004) as observed in $Q$. canbyi and J. flaccida (Fig. 3b). Species with high baseline, such as $P$. pseudostrobus, may exhibit osmotic adjustment only under mild water stress being at a disadvantage under severe drought conditions in mixed forest ecosystems, where species with low baseline $\Psi_{\mathrm{s}}$ predominate (Gebre et al. 1998). This could be an explanation for the similar course of the species' $\Psi_{\text {spd }}$ and $\Psi_{\text {smd }}$ curves in Plot-N compared to the xeric Plot-S, where P. pseudostrobus had definitively higher values (Fig. 3).

According to data from literature, American and European oak species in general have shown to be quite drought tolerant, due to their capacity of osmotic adjustment in response to water stress (Bahari et al. 1985; Abrams 1990; Epron and Dreyer 1993; Bréda et al. 1993; Aranda et al. 1996; Corcuera et al. 2002). So far and due to the highly significant difference in $\Psi_{\mathrm{s}}$ comparing a moist and dry sampling date, the higher capacity for osmotic adjustment could be one explanation for the remarkable seasonal fluctuation in $\Psi_{\mathrm{s}}$ and wide ranges in $\Delta \Psi_{\mathrm{w}}$ of $Q$. canbyi (Fig. 3).

Species of the genus Juniperus possess quite distinctive responses to drought compared with those of oaks (Bahari et al. 1985). Nevertheless, in the present study, the course of $\Psi_{\mathrm{s}}$ and $\Delta \Psi_{\mathrm{s}}$ showed similar pattern comparing J. flaccida with $Q$. canbyi (Fig. 3). In fact, the inherent ability of Juniperus species to sustain stomata opening at 
low water potentials combined with low capacity for water loss appear to promote the abundance of Juniperus in xeric environments. This in turn sustains the theory to categorise the water status regulation of $J$. flaccida as anisohydric (McDowell et al. 2008). Furthermore, species of Juniperus seems to possess numerous physiological and morphological characteristics that make them more drought tolerant than others species, such as efficient stem cavitation relationships, transpiration and photosynthetic responses, as well as the capacity to substantially reduce water stress through foliar absorption of intercepted rain (Lajtha and Barnes 1991; West et al. 2007; Breshears et al. 2009).

On a seasonal basis, gradual decrease in $\Psi_{\text {wpd }}$ and $\Psi_{\text {spd }}$ (Fig. 2) of J. flaccida and Q. canbyi showed a considerable response to soil-water availability pattern (Fig. 1). In addition, these evidences are sustained by the relationship found within the soil water content in the four soil layers, since it explained $\left(r^{2}\right)$ between $50 \%$ (Q. canbyi) and 56\% (J. flaccida) of the variation in $\Psi_{\text {wpd }}$ (Table 4), and the correlations with soil moisture at each particular soil depth (Table 3). Soil water content higher than $15 \%$ was required to achieve maximum (greater than $-1.5 \mathrm{MPa}$ ) and constant $\Psi_{\text {wpd; }}$ below this threshold value, $\Psi_{\text {wpd }}$ decreased gradually, mainly for J. flaccida (Fig. 4). A similar pattern of variation in $\Psi_{\text {wpd }}$, depending on the soil water content, has been described for other tree species (Hinckley and Ritchie 1973; Sellin 1998; Montagu and Woo 1999; González et al. 2004), and can be attributed primarily to the decrease in soil water content or rather to static water stress (Sellin 1998).

In contrast, there was no strong relationship found between soil water content and $\Psi_{\text {wpd }}$ of P. pseudostrobus (Tables 3 and 4), and correlations of $\Psi_{\mathrm{s}}$ with environmental variables were completely missing for this species. Since water potentials curves of isohydric species are more independent of soil water pattern (Tardieu and Simonneau 1998; McDowell et al. 2008), the lack of strong correlations with soil water content sustains further the isohydric behaviour of $P$. pseudostrobus.

The dynamic water stress, expressed by the depression potentials $\left(\Psi_{\mathrm{wd}}\right)$, was unexceptionally influenced by atmospheric conditions for the two conifers (Table 3). Only for $Q$. canbyi, $\Psi_{\mathrm{wd}}$ was mainly correlated with soil moisture content, a behaviour that indicates the species' dependence on soil water availability. So, daily pattern of $\Psi_{\text {wd }}$ reflected interaction between soil water dynamics and atmospheric evaporative demands (Sellin 1998).

\section{Conclusions}

Water status regulation during periods of drought was quite different comparing three native tree species and their leaf water and osmotic potentials in the course of 8 months. While $P$. pseudostrobus showed typical isohydric behaviour, J. flaccida and Q. canbyi, in contrast, seemed to exhibit anisohydric water status regulation. Thus, isohydric behaviour is of advantage during severe but short periods of drought, while anisohydric water status regulation is favourable during long-term drought conditions of minor intensity (Breshears et al. 2009). Detailed knowledge about the type of waters status regulation is crucial in the context of climate change for modelling future changes in forest vegetation. However, for precise conclusions about forest development in the Sierra Madre Oriental, further longterm studies are required including additional plant physiological variables, such as stomatal conductance, photosynthetic activity and carbon assimilation, as well as detailed forest inventories, monitoring spatial distribution, regeneration and tree survival.

Acknowledgments The study was funded in part by the Comisión Nacional Forestal and Consejo Nacional de Ciencia y Tecnología (CONAFOR-CONACYT, No. 2002-C01-5951) and the Universidad Autónoma de Nuevo León (UANL-PAICYT, No. CN 1133-05). We further would like to thank the Secretaría de Relaciónes Exteriores (SER) for the support by scholarship. We gratefully acknowledge the anonymous reviewers for their detailed and enriching comments. Valuable technical assistance provided by Juan José González Álvarez and Claudia Platas Villanueva is gratefully recognised.

\section{References}

Abrams MD (1990) Adaptations and responses to drought in Quercus species of North America. Tree Physiol 7:227-238. doi:10.1093/ treephys/7.1-2-3-4.227

Aranda I, Gil L, Pardos J (1996) Seasonal water relations of three broadleaved species [Fagus sylvatica L., Quercus petraea (Mattuschka) Liebl. and Quercus pyrenaica Willd.] in a mixed stand in the centre of the Iberian Pensinsula. For Ecol Manag 84: 219-229. doi: 10.1016/0378-1127(96)03729-2

Aranda I, Gil L, Pardos JA (2004) Osmotic adjustment in two temperate oak species [Quercus pyrenaica Willd and Quercus petraea (Matt.) Liebl] of the Iberian Peninsula in response to drought. Investigación agraria: Sist Recur For 13:339-345

Bahari ZA, Pallardy SG, Parker WC (1985) Photosynthesis, water relations, and drought adaptation in six woody species of oakhickory forests in central Missouri. For Sci 31:557-569

Bréda N, Cochard H, Dreyer E, Granier A (1993) Field comparison of transpiration, stomatal conductance and vulnerability to cavitation of Quercus petraea and Quercus robur under water stress. Ann For Sci 50:571-582. doi:10.1051/forest:19930606

Breshears DD, Myers OB, Meyer CW, Barnes FJ, Zou CB, Allen CD, McDowell NG, Pockman WT (2009) Tree die-off in response to global change-type drought: mortality insights from a decade of plant water potential measurements. Front Ecol Environ 7: 185-189. doi:10.1890/080016

Bucci SJ, Scholz FG, Goldstein G, Meinzer FC, Hinojosa JA, Hoffmann WA, Franco AC (2004) Processes preventing nocturnal equilibration between leaf and soil water potential in tropical savanna woody species. Tree Physiol 24:1119-1127. doi:10.1093/ treephys/24.10.1119 
Cantú I, González H (2002) Propiedades hidrológicas del dosel de los bosques de pino-encino en el noreste de México. Cienc UANL 5:72-77

Cochard H, Bréda N, Granier A (1996) Whole tree hydraulic conductance and water loss regulation in Quercus during drought: evidence for stomatal control of embolism? Ann Sci For 53:197-206. doi:10.1051/forest:19960203

Corcuera L, Camarero JJ, Gil-Pelegrín E (2002) Functional groups in Quercus species derived from the analysis of pressure-volume curves. Trees 16:465-472. doi:10.1007/s00468-002-0187-1

Crawley MJ (2007) The R book. John Wiley, New York

Domínguez PA, Návar JJ (2000) Einfluss der Pflanzenqualität von Pinus pseudostrobus Lindl. auf Überlebensrate und Wuchsleistung bei Aufforstungen in der östlichen Sierra Madre Mexikos. Forstarch 71:10-13

Donovan LA, Linton MJ, Richards JH (2001) Predawn plant wate potential does not necessarily equilibrate with soil water potential under well-watered conditions. Oecologia 129:328-335. doi: $10.1007 / \mathrm{s} 004420100738$

Donovan La, Richards JH, Linton MJ (2003) Magnitude and mechanisms of disequilibrium between predawn plant and soil water potential. Ecology 84:463-470. doi:10.1890/0012-9658 (2003)084[0463:MAMODB]2.0.CO;2

Duhme F, Richter H (1977) Druckkammermethode. In: Kreeb KH (ed) Methoden der Pflanzenökologie und Bioindikation. Stuttgart, New York

Epron D, Dreyer E (1993) Long-term effects of drought on photosynthesis of adult oak trees [Quercus petraea (Matt.) Liebl. And Quercus robur L.] in a natural stand. New Phytol 125: 381-389. doi: 10.1111/j.1469-8137.1993.tb03890.x

Franks DJ, Drake PL, Froend RH (2007) Anisohydric but isohydrodynamic: seasonally constant plant water potential gradient explained by a stomatal control mechanism incorporating variable plant hydraulic conductance. Plant Cell Environ 30: 19-30. doi:10.1111/j.1365-3040.2006.01600.x

Gallego HA, Rico M, Moreno G, Santa Regina I (1994) Leaf water potential and stomatal conductance in Quercus pyrenaica Willd forests: vertical gradients and response to environmental factors. Tree Physiol 14:1039-1047. doi:10.1093/treephys/14.7-8-9.1039

Gebre GM, Tschaplinski TJ, Shirshac TL (1998) Water relations of several hardwood species in response to throughfall manipulation in an upland oak forest during a moist year. Tree Physiol 18:299-305. doi:10.1093/treephys/18.5.299

Gebrehiwot K, Muys B, Haile M, Mitlöhner R (2005) The use of plant water relations to characterise tree species in sites in the drylands of northern Ethiopia. J Arid Environ 60:581-592. doi:10.1016/ j.jaridenv.2004.07.009

Gebrekirstos A, Teketay D, Fetene M, Mitlöhner R (2006) Adaptation of five co-occurring tree and shrub species to water stress and its implication in restoration of degraded lands. For Ecol Manag 229:259-267. doi:10.1016/j.foreco.2006.04.029

González Rodríguez H, Cantú Silva I, Gómez Meza MV, Ramírez Lozano RG (2004) Plant water relations of thornscrub shrub species, north-eastern Mexico. J Arid Environ 58:483-503. doi: 10.1016/j.jaridenv.2003.12.001

González Tagle MA, Himmelsbach W, Jiménez Pérez J, MüllerUsing B (2005) Reconstruction of fire history in pine-oak forests in the Sierra Madre Oriental, Mexico. Forstarch 76:138-143

González-E M, Jurado E, González-E S, Aguirre Calderón O, Jiménez Pérez J, Návar J (2003) Cambio climático mundial: origen y consecuencias. Cienc UANL 6:377-385

Hinckley TM, Ritchie GA (1973) A theoretical model for calculation of xylem sap pressure from climatological data. Am Midl Nat 90:56-69

Jurado E, Jiménez J, Treviño E (1998) Biodiversidad en peligro. Cienc UANL 1:43-47
Kavanagh KL, Pangle R, Schotzko AD (2007) Nocturnal transpiration causing desequilibrium between soil and stem predawn water potential in mixed conifer forests of Idaho. Tree Physiol 27:621-629. doi:10.1093/treephys/27.4.621

Kolb TE, Stone JE (2000) Differences in leaf gas exchange and water relations among species and tree sizes in an Arizona pine-oak forest. Tree Physiol 20:1-12. doi:10.1093/treephys/20.1.1

Kozlowski TT, Kramer PJ, Pallardy SG (1991) The physiological ecology of woody plants. Academic Press, Inc, San Diego

Kramer PJ (1980) Drought stress and the origin of adaptations. In: Turner NC, Kramer PJ (eds) Adaptation of plants to water and high temperature stress. Wiley, New York, pp 7-22

Kramer PJ (1983) Water relations of plants. Academic Press, New York

Kramer PJ, Boyer JS (1995) Water relations of plants and soils. Academic Press, San Diego

Lajtha K, Barnes FJ (1991) Carbon gain and water use in pinyon-juniper woodlands of northern New Mexico: field vs phytotron chamber measurements. Tree Physiol 9:59-67. doi:10.1093/treephys/9. $1-2.59$

Lassoie JP, Dougherty PM, Reich PB, Hinckley TM, Metcalf CM, Dina SJ (1983) Ecophysiological investigations of understory eastern redcedar in Central Missouri. Ecology 64:1355-1366. doi: $10.2307 / 1937490$

Loewenstein NJ, Pallardy SG (1998a) Drought tolerance, xylem sap abscisic acid and stomatal conductance during soil drying: a comparison of young plants of four temperate deciduous angiosperms. Tree Physiol 18:421-430. doi:10.1093/treephys/ 18.7.421

Loewenstein NJ, Pallardy SG (1998b) Drought tolerance, xylem sap abscisic acid and stomatal conductance during soil drying: a comparison of canopy trees of three temperate deciduous angiosperms. Tree Physiol 18:431-439. doi:10.1093/treephys/ 18.7.431

McDowell N, Pockman WT, Allen CD, Breshears DD, Cobb N, Kolb T, Plaut J, Sperry J, West A, Williams DG, Yepez EA (2008) Mechanisms of plant survival and mortality during drought: why do some plants survive while others succumb to drought? New Phytol 178:719-739. doi:10.1111/j.1469-8137.2008.02436.x

Mitloehner R, Koepp R (2007) Bioindicator capacity of trees towards dryland salinity. Trees 21:411-419. doi:10.1007/s00468-0070133-3

Mitlöhner R (1997) Using trees as indicators of environmental conditions by measuring their internal water status. Plant Res Dev 45:33-55

Mitlöhner R (1998) Planzeninterne Potentiale als Indikatoren für den tropischen Standort. Shaker Verlag, Aachen

Montagu KD, Woo KC (1999) Recovery of tree photosynthetic capacity from seasonal drought in the wet-dry tropics: the role of phyllode and canopy processes in Acacia auriculiformis. Aust $\mathrm{J}$ Plant Physiol 26:135-145. doi:10.1071/PP98034

Morecroft MD, Roberts JM (1999) Photosynthesis and stomatal conductance of mature canopy oak (Quercus robur) and sycamore (Acer pseudoplatanus) trees throughout the growing season. Funct Ecol 13:332-342. doi:10.1046/j.1365-2435.1999.00327.x

Morgan JM (1980) Osmotic adjustment in the spikelets and leaves of wheat. J Exp Bot 31:655-665. doi:10.1093/jxb/31.2.655

Morgan JM (1984) Osmoregulation and water stress in higher plants. Ann Rev Plant Physiol 35:299-319. doi:10.1146/annurev.pp.35. 060184.001503

Munns R (2002) Comparative physiology of salt and water stress. Plant Cell Environ 25:239-250. doi:10.1046/j.0016-8025.2001. 00808.x

Nguyen-Queyrens A, Costa P, Loustau D, Plomion C (2002) Osmotic adjustment in Pinus pinaster cuttings in response to a soil drying cycle. Ann For Sci 59:795-799. doi:10.1051/forest:2002067 
Otieno DO, Schmidt MWT, Kurz-Besson C, Lobo do Vale R, Pereira JS, Tenhunen JD (2007) Regulation of transpirational water loss in Quercus suber trees in a Mediterranean-type ecosystem. Tree Physiol 27:1179-1187. doi:10.1093/treephys/27.8.1179

Pallardy SG, Pereira JS, Parker WC (1991) Measuring the state of water in tree systems. In: Lassoie JP, Hinckley TM (eds) Techniques and approaches in forest tree ecophysiology. CRC press, Boston, pp 27-78

Pastor J, Post WM (1988) Response of northern forests to $\mathrm{CO}_{2}$-induced climate change. Nature 334:55-58. doi:10.1038/334055a0

Philip JR (1966) Plant water relations: some physical aspects. Ann Rev Plant Physiol 17:245-268. doi:10.1146/annurev.pp.17.060166. 001333

Pothier D, Bédard M, Caissy R, Stein J (1989) Variations du potential hydrique de plants d'épinette noire en pépinière en function de variables météorologiques. Nat Can 116:61-68

Pressarakli M (1991) Formation of saline and sodic soils and their reclamation. J Environ Sci Health A 26:1303-1320. doi:10.1080/ 10934529109375698

Quintana-Ascencio PF, Ramírez-Marcial N, González-Espinosa M, Martínez-Icó M (2004) Sapling survival and growth of coniferous and broad-leaved trees in successional highland habitats in Mexico. Appl Veg Sci 7:81-88. doi:10.1658/1402-2001(2004) 007[0081:SSAGOC]2.0.CO;2

Ramírez-Marcial N, González-Espinosa M, García-Moya E (1996) Establecimiento of Pinus spp. y Quercus spp. en matorrales y pastizales de Los Altos de Chiapas, México. Agrocienc 30: 249-257

Ramírez-Marcial N, González-Espinosa M, Williams-Linera G (2001) Anthropogenic disturbance and tree diversity in montane rain forests in Chiapas, Mexico. For Ecol Manag 154:311-326. doi:10.1016/S0378-1127(00)00639-3

Ricker M, Gutiérrez García G, Daly DC (2007) Modeling long-term tree growth curves in response to warming climate: test cases from a subtropical mountain forest and a tropical rainforest in Mexico. Can J For Res 37:977-989. doi:10.1139/X06-304

Rötzer T, Grote R, Pretzsch H (2005) Effects of environmental changes on the vitality of forest stands. Eur J For Res 124: 349-362. doi:10.1007/s10342-005-0086-2

Rzedowski J (1986) Vegetación de México. 3rd edn, Editorial Limusa, S.A. de C.V., Mexico

Sala OE, Laucnroth WK, Parton WJ, Trlica MJ (1981) Water status of soil and vegetation in a shortgrass steppe. Oecol 48:327-331. doi:10.1007/BF00346489

Scholander PF, Hammel HT, Bradstreet ED, Hemmingsen EA (1965) Sap pressure in vascular plants. Sci 148:339-346. doi:10.1126/ science.148.3668.339

Sellin A (1996) Base water potential in shoots of Picea abies as a characteristics of soil water status. Plant Soil 184:273-280. doi: 10.1007/BF00010456

Sellin A (1998) The dependence of water potential in shoots of Picea abies on air and soil water status. Ann Geophys 16:470-476. doi: 10.1007/s00585-998-0470-6
Sellin A (1999) Does pre-dawn water potential reflect conditions of equilibrium in plant and soil water status? Acta Oecol 20(1): 51-59. doi:10.1016/S1146-609X(99)80015-0

Slatyer RO (1967) Plant water relationships. Academic Press, London

Szabolcs I (1994) Soils and salinization. In: Pressarakli M (ed) Handbook of plant and crop stresses. Dekker, New York

Tardieu F (1993) Will increases in our understanding of soil-root relations and root signalling substantially alter water flux models? Phil trans R Soc Lond B 341:57-66. doi:10.1098/ rstb.1993.0091

Tardieu F, Simonneau T (1998) Variability among species of stomatal control under fluctuating soil water status and evaporative demand: modelling isohydric and anisohydric behaviours. J Exp Bot 49:419-432. doi:10.1093/jxb/49.Special_Issue.419

Tschaplinski TJ, Gebre GM, Shirshac TL (1998) Osmotic potential of several hardwood species as affected by manipulation of throughfall precipitation in an upland oak forest during a dry year. Tree Physiol 18:291-298. doi:10.1093/treephys/18.5.291

Tyree MT, Ewers FW (1991) The hydraulic architecture of trees and other woody plants. New Phytol 119:345-360. doi:10.1111/j. 1469-8137.1991.tb00035.x

Vertovec M, Sakçali S, Ozturk M, Salleo S, Giacomich P, Feoli E, Nardini A (2001) Diagnosing plant water status as a tool for quantifying water stress on a regional basis in Mediterranean drylands. Ann For Sci 58:113-125. doi:10.1051/forest:2001111

West AG, Hultine KR, Jackson TL, Ehleringer JR (2007) Differential summer water use by Pinus edulis and Juniperus osteosperma reflects contrasting hydraulic characteristics. Tree Physiol 27: 1711-1720. doi: 10.1093/treephys/27.12.1711

West AG, Hultine KR, Sperry JS, Bush SE, Ehleringer JR (2008) Transpiration and hydraulic strategies in a piñon-juniper woodland. Ecol Appl 18:911-927. doi:10.1890/06-2094.1

Williams DG, Ehleringer JR (2000) Intra- and interspecific variation for summer precipitation use in pinyon-juniper woodlands. Ecol Monogr 73:223-239. doi:10.1890/0012-9615(2000)070[0517: IAIVFS]2.0.CO;2

Wilson JR, Fisher MJ, Schulze ED, Dolby GR, Ludlow MM (1979) Comparison between pressure-volume and dewpoint-hygrometry techniques for determining the water relations characteristics of grass and legume leaves. Oecol (Berl) 41:77-88. doi:10.1007/ BF00344838

$\mathrm{Xu} \mathrm{L}$, Baldocchi DD (2003) Seasonal trends in photosynthetic parameters and stomatal conductance of blue oak (Quercus douglasii) under prolonged summer drought and high temperature. Tree Physiol 23:865-877. doi:10.1093/treephys/23.13.865

Zar JH (1999) Biostatistical analysis. Prentice-Hall Inc, New Jersey

Zunzunegui M, Díaz Barradas MC, Ain-Lhout F, Clavijo A, García Novo F (2005) To live or survive in Doñana dunes: Adaptive responses of woody species under a Mediterranean climate. Soil Plant 273:77-89. doi:10.1007/s11104-004-6806-4 